Research Article

\title{
Assessment of inhalation technique and predictors of incorrect performance among patients of chronic obstructive pulmonary disease and asthma
}

\author{
Tulika Jha ${ }^{1}$, Ashok Kumar Sahai ${ }^{1}$, Malay Sarkar ${ }^{2}$, Purshottam Kumar Kaundal ${ }^{1}$, \\ Praveen Bhardwaj ${ }^{3}$, Indrajeet Sharma ${ }^{4}$
}

\begin{abstract}
${ }^{1}$ Department of Pharmacology, ${ }^{2}$ Department of Pulmonary Medicine, ${ }^{3}$ Department of Paediatrics, Indira Gandhi Medical College, Shimla-1, Himachal Pradesh, India, ${ }^{4}$ Department of Pharmacology, AIMS, Rajsamand, India
\end{abstract}

Received: 03 June 2016 Accepted: 04 July 2016

*Correspondence to:

Dr. Tulika Jha,

Email: drtulij@gmail.com

Copyright: () the author(s), publisher and licensee Medip Academy. This is an openaccess article distributed under the terms of the Creative Commons Attribution NonCommercial License, which permits unrestricted noncommercial use, distribution, and reproduction in any medium, provided the original work is properly cited.

\begin{abstract}
Background: Poor inhalation technique is responsible for decreasing the efficacy of topical drug therapy in asthma and chronic obstructive pulmonary disease (COPD). Certain steps of the inhalation technique are erred most often and if ascertained, can be rectified leading to an overall improvement in the technique. The predictors for poor use can also be marked.

Methods: Inhaler technique for pressurised metered dose inhalers (pMDI), pressurised metered dose inhaler with spacer and dry powder inhaler (DPI) was assessed in one hundred and five patients who fulfilled the inclusion and exclusion criteria and were enrolled in this study. Inhaler technique was assessed using an ERAS/ISAM Task force report based scores and the lung function using pulmonary function test (PFT).The technique was re-assessed and scored after a period of three months along with the assessment of the lung function by PFT.

Results: The mean of ERS/ISAM task force report based score for evaluation of the techniques of inhalation increased from $5.79 \pm 2.58$ to $8.23 \pm 2.41$ $(\mathrm{p}<0.0001)$ after intervention. The most commonly committed error in the inhalation technique was in step number eight, ten and four by patients using pMDI, pMDI with spacer and DPI, respectively. The faulty technique being the dependent variable/outcome could be explained $16 \%$ by the type of inhaler used $(\mathrm{r} 2=0.1607)$ and this is statistically significant $(\mathrm{p}<0.0001)$, thus the type of inhaler used was a predictor of poor use.

Conclusions: Inhaler techniques improved with systematic training and there was a trend towards improvement in lung function, hence the clinical condition.
\end{abstract}

Keywords: Asthma, COPD, DPI, ERS/ISAM, pMDI+Spacer

\section{INTRODUCTION}

The inhaled route is preferred for the delivery of bronchodilators and corticosteroids used in the maintenance therapy of asthma and chronic COPD. Small doses of drugs are delivered straightaway to their site of action, leading to rapid onset of action and lowering incidence of side effects. ${ }^{1}$ It is quite difficult to source advice about the choice of inhaler device, despite the availability of several different types. ${ }^{2-4}$ The American college of chest physicians (ACCP) recently published evidence-based guidelines that listed eight points for consideration when selecting an inhaler, including taking account of any specific device preference the patient or clinician might have and whether a given patient can use the device properly. ${ }^{5}$

Correct pMDI technique involves firing the pMDI, while breathing in deeply and slowly, and then following inhalation with a breath-holding pause to allow particles to sediment on the airway surfaces. ${ }^{6,7}$ Most importantly, the pMDI must not be fired after the inhalation is 
completed, as then there is no air-stream to carry the aerosol into the lungs. Some aerosol will probably still reach the lungs if the pMDI is fired shortly before inhalation starts. If the patient mistimes the firing of pMDI with inhalation, it is termed as "poor coordination". 8

Spacers overcome coordination problems because inhalation can take place either as the device is fired into the spacer or after a short pause. ${ }^{9}$ While spacers are good drug-delivery devices, they are not portable, convenient and compact as a standard pMDI. ${ }^{9}$

Dry-powder inhalers (DPIs), including aerolizer, diskus, handihaler, and turbuhaler, are flow dependent devices and need very less patient-device coordination. ${ }^{10-12}$

Patients might have received treatment, but without proper education and training in correct handling of the inhaler, the therapeutic benefit is less than optimal. ${ }^{11} \mathrm{~A}$ high proportion of patients do not have the proficiency to use their device effectively because they have forgotten what they were taught and no longer put to use the correct technique that they were trained to apply. ${ }^{12}$ For this reason, international guidelines for asthma and COPD management state that inhalation technique should be assessed regularly and rectified if it is inadequate. ${ }^{13,14}$

There is evidence of the positive effect of teaching to achieve correct inhaler use as was seen in our study where a remarkable increase in the ERAS/ISAM task force report based score was noted post-training. ${ }^{15,16}$

The interaction of pulmonary function test, inhaler type and training in inhalational technique has implications that are not portrayed adequately by mere calculation of inhaler-based error rates in the overall groups. However, there are studies that have noted an improvement in the clinical outcomes in patients with asthma and COPD after teaching patients how to inhale correctly. ${ }^{17,18}$

The type of inhaler used could be considered a predictor for poor use as patients using pMDI were found to make more mistakes as compared to those using pMDI with spacer device and DPI. This finding was corroborated by a study by van der Palen et al with asthma patients who found that the percentage of patients performing all the essential steps of inhaler use was greater when a combination of DPIs was used, compared to a combination of an MDI and DPI. ${ }^{19}$

In the present study, we made an effort to find the most commonly erred step with the various inhalers at baseline and the improvement seen after training thereby gauging the effect on clinical outcome. The predictor for poor use was also noted.

\section{METHODS}

Study population and selection process: The patient population screened for recruitment to the study were those attending outpatient services of pulmonary medicine department. The COPD and Asthma patients who fulfilled the inclusion and exclusion criteria and gave written informed consent either themselves or through their relatives were subjected to a detailed history pertaining to demographics, socioeconomic status, duration of symptoms, type of device used, duration of device use, educator, as per a structured questionnaire following which enrolment of the patients for the study was done. They were then asked by the investigator to demonstrate the inhaler technique without any prompts, critiques or oral instructions either before or during the demonstration. The technique was evaluated by awarding one point for each correct step based on recommended guidelines of ERAS/ISAM task force report. ${ }^{16}$ Thereafter, the incorrect step was corrected through physical demonstration using a placebo device and the patient was asked to perform the technique again. This process was repeated till the patient got all the steps of the inhaler technique right.

The number and percentage of patients committing error at different steps was calculated for each inhaler used in the study at baseline and three months after intervention.

The most commonly erred step was also taken into account with respect to the number of patients performing that particular step incorrectly at baseline and after three months. The predictor of poor use of the inhalers was ascertained. The pulmonary function was assessed at baseline and the values of variables were noted. After three months, the same procedure was followed to assess the handling of inhaler and the variables of pulmonary function test were also recorded.

\section{Setup and study design}

The study was prospective, non-randomized, observational and interventional conducted during the time period of one year ensuing from $1^{\text {st }}$ July 2014 till $30^{\text {th }}$ June 2015 on an out-patient basis in the department of pulmonary medicine at Indira Gandhi Medical College, Shimla, Himachal Pradesh, India. The study protocol was approved by IGMC ethical committee.

\section{Instructions for inhalers}

The detailed instructions on how to use pressurised metered dose inhalers, dry powder inhalers and pressurised metered dose inhalers with spacer device was as per guidelines in ERAS/ISAM task force report. ${ }^{16}$

Detailed instructions on how to use pressurised metereddose inhalers (pMDIs), pMDIs with spacers, dry powder inhalers (DPIs). 


\section{pMDIs for patients with good actuation-inhalation coordination}

- Shake four or five times if suspension formulation

- Take the cap off

- Prime the inhaler (refer to the PIL for specific instructions)

- Exhale slowly, as far as comfortable (to empty the lungs)

- Hold the inhaler in an upright position.

- Immediately place the inhaler in the mouth between the teeth, with the tongue flat under the mouthpiece.

- Ensure that the lips have formed a good seal with the mouthpiece.

- Start to inhale slowly, through the mouth and at the same time press the canister to actuate a dose.

- Maintain a slow and deep inhalation, through the mouth, until the lungs are full of air. This should take an adult $4-5 \mathrm{~s}$.

- At the end of the inhalation, take the inhaler out of the mouth and close the lips.

- Continue to hold the breath for as long as possible, or up to 10 s before breathing out.

- Breathe normally.

- If another dose is required, repeat steps 4-12.

\section{pMDI+Spacer}

- Shake four or five times if suspension formulation

- Take the cap off

- $\quad$ Prime the inhaler

- Insert the mouthpiece of the pMDI into the open end of the spacer and ensure a tight fit

- Place the mouthpiece of the spacer in the patient's mouth with the teeth over the mouthpiece and the lips sealed around it

- Instruct the patients to exhale slowly as far as comfortable (to empty their lungs)

- Actuate one dose into the chamber of the spacer and start to inhale slowly through the mouthpiece. Some spacers will make a whistling noise if inspiration is too fast

- Maintain a slow and deep inhalation through the mouth, until the lungs are full of air. This should take a child $2-3 \mathrm{~s}$ and an adult $5 \mathrm{~s}$.

- At the end of the inhalation, take the inhaler out of the mouth and close the lips.

- Continue to hold the breath for as long as possible for up to 10 s before breathing out

- Breathe normally

- If another dose is required, repeat steps 1-11

- If ICSs are used, rinse mouth afterwards

DPIs: for patients >5-6 years old (caregiver should determine if child canperform this technique correctly)

- Take the cap off (some do not have a cap)

- Follow the dose preparation instructions
- Do not point the mouthpiece downwards once a dose has been prepared for inhalation because the dose could fall out

- Exhale slowly, as far as comfortable (to empty the lungs). Do not exhale into the DPI

- Start to inhale forcefully through the mouth from the very beginning. Do not gradually build up the speed of inhalation

- Continue inhaling until the lungs are full

- At the end of the inhalation take the inhaler out of the mouth and close the lips. Continue to hold the breath for as long as possible, or up to $10 \mathrm{~s}$

- Breathe normally

- If another dose is required, repeat steps 1-8.

\section{Follow up period}

All the patients were properly examined after a period of three months. The dose of usual care medication was adjusted as per discretion of the treating physician. Five patients were lost to follow up thus hundred patients were analysed at the end of the study.

\section{Statistical analysis}

The data was reported as percentages and mean \pm SD for categorical and continuous variables respectively. The differences in the distribution of categorical variables between study groups were compared by $\chi 2$ test and unpaired students t-test for continuous variable. Regression analysis was applied to ascertain the independent variables of faulty technique of inhalation. 2 tailed significance at value $<0.05$ was taken as statistically significant. Data was analysed using Epi Info version 3.4.3.

\section{RESULTS}

Baseline clinical characteristics of the study group: A total of one hundred and forty patients were screened, out of which one hundred and five patients were enrolled for the study that fulfilled inclusion and exclusion criteria. One hundred patients were analysed as five could not be followed up. The mean age of the patients in years was $46.46 \pm 16.25$. There was female predominance with $66.0 \%$ females. Majority of the patients $(58 \%)$ lived in rural areas and were housewives (52\%). Most of the patients $(35 \%)$ belonged to class III of modified Prasad's BG socio-economic status classification of 2013. Majority of the patients $(73 \%)$ were diagnosed with asthma while a small proportion $(27 \%)$ out of the hundred patients was diagnosed with chronic obstructive pulmonary disease (COPD). The severity of asthma was of mild persistent type in most of the patients $(38.4 \%)$ among those diagnosed with the disease. Among those diagnosed with COPD, majority (51.9\%) of the patients belonged to Stage III. Majority of the patients $(73 \%)$ were using dry powder inhaler (DPI) followed by a small proportion (17\%) using pressurised metered dose inhaler with spacer (pMDI+Spacer), while only $10 \%$ of the patients were using pMDI alone. The duration of device use was less than one year in most of the patients $(45 \%)$. The educator was the physician in the majority $(63 \%)$ of the patients 
while the second largest proportion (29\%) of the patients was taught the method of inhalation by the hospital staff.

\section{Inhaler technique assessment}

The mean of ERS/ISAM task force report based score for evaluation of the techniques of inhalation for the three types of inhalers being used in our study came out to be $5.79 \pm 2.58$ at baseline. After a follow up duration of three months, this score was reassessed and its mean was $8.23 \pm 2.41$ which was highly significant statistically $(\mathrm{p}<0.0001)$.

Table 1: Patients performing all steps of inhalation technique correctly at baseline.

\begin{tabular}{|lll|}
\hline $\begin{array}{l}\text { Type of } \\
\text { inhaler }\end{array}$ & $\begin{array}{l}\text { No. of patients } \\
\text { (percentage) }\end{array}$ & $\begin{array}{l}\text { Total no. of } \\
\text { patients }\end{array}$ \\
\hline pMDI & $0(0 \%)$ & 10 \\
\hline pMDI+Spacer & $0(0 \%)$ & 17 \\
\hline DPIs & $9(12.3 \%)$ & 73 \\
\hline
\end{tabular}

Table 2: Patients performing all steps of inhalation technique correctly after intervention.

\begin{tabular}{|lll|}
\hline $\begin{array}{l}\text { Type of } \\
\text { inhaler }\end{array}$ & $\begin{array}{l}\text { No. of patients } \\
\text { (percentage) }\end{array}$ & $\begin{array}{l}\text { Total no. of } \\
\text { patients }\end{array}$ \\
\hline pMDI & $1(10 \%)$ & 10 \\
\hline pMDI+Spacer & $2(11.7 \%)$ & 17 \\
\hline DPIs & $20(27.4 \%)$ & 73 \\
\hline
\end{tabular}

None of the patients using pMDI and pMDI+Spacer device performed all steps of the inhalational technique correctly at baseline while nine $(12 \%)$ out of seventy three patients using DPI performed all steps correctly at baseline. After intervention, the percentage of patients performing all steps correctly using pMDI, pMDI+Spacer and DPI rose to $10 \%, 11.7 \%$ and $27.4 \%$, respectively. (Tables 1 and 2).

Table 3: Error committed at different steps of pMDIs by the patients.

\begin{tabular}{|c|c|c|c|c|c|}
\hline $\begin{array}{l}\text { Device: pMDIs } \\
\text { Steps No. }\end{array}$ & $\begin{array}{l}\text { Detailed instructions on how to use } \\
\text { the device }\end{array}$ & \multicolumn{2}{|c|}{$\begin{array}{l}\text { No. of patients committing } \\
\text { the error }\end{array}$} & \multicolumn{2}{|c|}{$\begin{array}{l}\text { Percentage }(\%) \text { of } \\
\text { patients committing the } \\
\text { error }\end{array}$} \\
\hline & & $\begin{array}{l}\text { At } \\
\text { baseline }\end{array}$ & \multirow{2}{*}{$\begin{array}{l}\text { After } \\
\text { intervention } \\
3\end{array}$} & \multirow{2}{*}{$\begin{array}{l}\text { At } \\
\text { baseline } \\
70 \%\end{array}$} & \multirow{2}{*}{$\begin{array}{l}\begin{array}{l}\text { After } \\
\text { intervention }\end{array} \\
30 \%\end{array}$} \\
\hline 1. & Shake four or five times if suspension formulation & 7 & & & \\
\hline 2. & Take the cap off & 0 & 0 & $0 \%$ & $0 \%$ \\
\hline 3. & $\begin{array}{l}\text { Prime the inhaler (refer to the PIL for specific } \\
\text { instructions) }\end{array}$ & 0 & 0 & $0 \%$ & $0 \%$ \\
\hline $\begin{array}{l}\text { Ex } \\
\text { lu }\end{array}$ & $\begin{array}{l}\text { Exhale slowly, as far as comfortable (to empty the } \\
\text { lungs) }\end{array}$ & 9 & 8 & $90 \%$ & $80 \%$ \\
\hline 5. & Hold the inhaler in an upright position & 2 & 0 & $20 \%$ & $0 \%$ \\
\hline $\begin{array}{l}\text { In } \\
\text { be } \\
\text { m }\end{array}$ & $\begin{array}{l}\text { Immediately place the inhaler in the mouth } \\
\text { between the teeth, with the tongue flat under the } \\
\text { mouthpiece }\end{array}$ & 7 & 3 & $70 \%$ & $30 \%$ \\
\hline $\begin{array}{l}\mathrm{El} \\
\text { th }\end{array}$ & $\begin{array}{l}\text { Ensure that the lips have formed a good seal with } \\
\text { the mouthpiece }\end{array}$ & 7 & 3 & $70 \%$ & $30 \%$ \\
\hline $\begin{array}{l}\text { St } \\
\text { th }\end{array}$ & $\begin{array}{l}\text { Start to inhale slowly, through the mouth and at } \\
\text { the same time press the canister to actuate a dose }\end{array}$ & 10 & 9 & $100 \%$ & $90 \%$ \\
\hline $\begin{array}{l}\mathrm{M} \\
\mathrm{m} \\
\mathrm{an}\end{array}$ & $\begin{array}{l}\text { Maintain a slow and deep inhalation, through the } \\
\text { mouth, until the lungs are full of air. This should tak } \\
\text { an adult 4-5s }\end{array}$ & & 6 & $80 \%$ & $60 \%$ \\
\hline 10. & $\begin{array}{l}\text { At the end of the inhalation, take the inhaler out } \\
\text { of the mouth and close the lips }\end{array}$ & 8 & 6 & $80 \%$ & $60 \%$ \\
\hline 11. & $\begin{array}{l}\text { Continue to hold the breath for as long as } \\
\text { possible, or up to } 10 \mathrm{~s} \text { before breathing out }\end{array}$ & 9 & 7 & $90 \%$ & $70 \%$ \\
\hline 12. & Breathe normally & 7 & 0 & $70 \%$ & $0 \%$ \\
\hline 13. & If another dose is required, repeat steps $4-12$ & 10 & 9 & $100 \%$ & $90 \%$ \\
\hline
\end{tabular}

The number and percentage of patients committing errors at each step of inhalation with the inhalers used in our study was also recorded both at baseline and after intervention where we can see that the number of patients committing error at each step of inhalation has reduced (Tables 3, 4 and 5). Thus, we were able to find out the most commonly erred step with the inhalers and how the number of patients making that mistake reduced after 
systematic training (Tables 6 and 7). With pMDI, the step which was most commonly performed incorrectly was step number four of ERAS/ISAM task force report based score that is about coordinating actuation of the dose of inhaled drug with inhalation. None of the patients $(0 \%)$ using pMDI could perform this step correctly at baseline while $90 \%$ of the patients performed this step incorrectly after three months that is after first intervention.

Table 4: Error committed at different steps of pMDIs+Spacer by the patients.

\begin{tabular}{|c|c|c|c|c|c|}
\hline \multirow[t]{2}{*}{$\begin{array}{l}\text { Device: } \\
\text { pMDIs+Spacer } \\
\text { Steps No. }\end{array}$} & \multirow[t]{2}{*}{$\begin{array}{l}\text { Detailed instructions on how to use the } \\
\text { device }\end{array}$} & \multicolumn{2}{|c|}{$\begin{array}{l}\text { No. of patients } \\
\text { committing the error }\end{array}$} & \multicolumn{2}{|c|}{$\begin{array}{l}\text { Percentage }(\%) \text { of } \\
\text { patients committing } \\
\text { the error }\end{array}$} \\
\hline & & $\begin{array}{l}\text { At } \\
\text { baseline }\end{array}$ & $\begin{array}{l}\text { After } \\
\text { intervention }\end{array}$ & $\begin{array}{l}\text { At } \\
\text { baseline }\end{array}$ & $\begin{array}{l}\text { After } \\
\text { intervention }\end{array}$ \\
\hline 1. & $\begin{array}{l}\text { Shake four or five times if suspension } \\
\text { formulation }\end{array}$ & 13 & 11 & $76.5 \%$ & $64.7 \%$ \\
\hline 2. & Take the cap off & 0 & 0 & $0 \%$ & $0 \%$ \\
\hline 3. & $\begin{array}{l}\text { Prime the inhaler (refer to the PIL for specific } \\
\text { instructions) }\end{array}$ & 0 & 0 & $0 \%$ & $0 \%$ \\
\hline 4. & $\begin{array}{l}\text { Insert the mouthpiece of the pMDI into the } \\
\text { open end of the spacer and ensure a tight fit. If } \\
\text { a reverse flow spacer is used, insert the valve } \\
\text { stem of the pMDI into the port on the } \\
\text { mouthpiece of the spacer }\end{array}$ & 6 & 3 & $35.3 \%$ & $17.6 \%$ \\
\hline 5. & $\begin{array}{l}\text { Place the mouthpiece of the spacer in the } \\
\text { patient's mouth with the teeth over the } \\
\text { mouthpiece and the lips sealed around it }\end{array}$ & 7 & 4 & $41.2 \%$ & $23.5 \%$ \\
\hline 6. & $\begin{array}{l}\text { Instruct the child to exhale slowly, as far as } \\
\text { comfortable (to empty their lungs) }\end{array}$ & 16 & 10 & $94.1 \%$ & $58.8 \%$ \\
\hline 7. & $\begin{array}{l}\text { Actuate one dose into the chamber of the } \\
\text { spacer and start to inhale slowly through the } \\
\text { mouthpiece. Some spacers will make a } \\
\text { whistling noise if inspiration is too fast }\end{array}$ & 10 & 6 & $58.8 \%$ & $35.3 \%$ \\
\hline 8. & $\begin{array}{l}\text { Maintain a slow and deep inhalation through } \\
\text { the mouth, until the lungs are full of air. This } \\
\text { should take a child } 2-3 \mathrm{~s} \text { and an adult } 5 \mathrm{~s}\end{array}$ & 12 & 8 & $70.6 \%$ & $47.1 \%$ \\
\hline 9. & $\begin{array}{l}\text { At the end of the inhalation, take the inhaler } \\
\text { out of the mouth and close the lips }\end{array}$ & 15 & 9 & $88.2 \%$ & $52.9 \%$ \\
\hline 10. & $\begin{array}{l}\text { Continue to hold the breath for as long as } \\
\text { possible for up to } 10 \mathrm{~s} \text { before breathing out }\end{array}$ & 17 & 15 & $100 \%$ & $88.2 \%$ \\
\hline 11. & Breathe normally & 6 & 2 & $35.3 \%$ & $11.8 \%$ \\
\hline 12. & If another dose is required, repeat steps $1-11$ & 17 & 15 & $100.0 \%$ & $88.2 \%$ \\
\hline 13. & If ICSs are used, rinse mouth afterwards & 16 & 14 & $94 \%$ & $82.4 \%$ \\
\hline
\end{tabular}

The most commonly performed mistake while using pMDI+Spacer was seen in step number ten of ERAS/ISAM task force report based score which includes breath holding for as long as possible for up to ten seconds at the end of inhalation. None of the patients $(0 \%)$ performed this step correctly at baseline while after intervention, $88 \%$ of those using pMDI+Spacer performed this step incorrectly.

In the patients using DPI, the most commonly erred step was number four of the ERAS/ISAM task force report based score which requires the patient to exhale slowly (as far as comfortable) to empty the lungs before proceeding to start inhalation from the device. It was noted that $87.6 \%$ of the patients using DPIs committed this mistake at the outset while after training this decreased to $72.6 \%$ of the patients using DPIs. The type of inhaler being used emerged as the predictor of poor use of the inhalers. The faulty technique being the dependent variable/outcome could be explained $16 \%$ by the type of inhaler used $(\mathrm{r} 2=0.1607)$, and it came out to be statistically significant $(\mathrm{p}<0.0001)$.

The faulty technique being the dependent variable/outcome could be explained $1.5 \%$ by the educator of the inhalation technique $(\mathrm{r} 2=0.0147)$ but this 
was statistically insignificant $(\mathrm{p}=0.2300)$. So, the educator could not be considered a predictor of poor handling of inhalers.

\section{Pulmonary function test}

The mean SVC, FVC, FEV1, FEF $25-75 \%$ and FEV1/FVC were 63.49 $\pm 11.98, \quad 60.48 \pm 12.71$,
$55.69 \pm 14.16,55.69 \pm 14.16$ and $83.69 \pm 18.92$, respectively. These baseline pulmonary function test variables were reassessed after three months of intervention that increased to $65.42 \pm 11.08,61.59 \pm 11.91,56.97 \pm 13.71$, $29.82 \pm 17.95$ and $84.79 \pm 18.84$ (p value non-significant).

Table 5: Error committed at different steps of DPIs by the patients.

\begin{tabular}{|c|c|c|c|c|c|}
\hline \multirow[t]{2}{*}{$\begin{array}{l}\text { Device: } \\
\text { DPIs } \\
\text { Steps No. }\end{array}$} & \multirow[t]{2}{*}{ Detailed instructions on how to use the device } & \multicolumn{2}{|c|}{$\begin{array}{l}\text { No. of patients } \\
\text { committing the error }\end{array}$} & \multicolumn{2}{|c|}{$\begin{array}{l}\text { Percentage }(\%) \text { of } \\
\text { patients committing the } \\
\text { error }\end{array}$} \\
\hline & & $\begin{array}{l}\text { At } \\
\text { baseline }\end{array}$ & $\begin{array}{l}\text { After } \\
\text { intervention }\end{array}$ & $\begin{array}{l}\text { At } \\
\text { baseline }\end{array}$ & $\begin{array}{l}\text { After } \\
\text { intervention }\end{array}$ \\
\hline 1. & Take the cap off (some do not have a cap) & 0 & 0 & $0 \%$ & $0 \%$ \\
\hline 2. & Follow the dose preparation instructions in the PIL & 0 & 0 & $0 \%$ & $0 \%$ \\
\hline 3. & $\begin{array}{l}\text { Do not point the mouthpiece downwards once a } \\
\text { dose has been prepared for inhalation because the } \\
\text { dose could fall out }\end{array}$ & 10 & 4 & $13.7 \%$ & $5.5 \%$ \\
\hline 4. & $\begin{array}{l}\text { Exhale slowly, as far as comfortable (to empty the } \\
\text { lungs). Do not exhale into the DPI }\end{array}$ & 64 & 53 & $87.7 \%$ & $72.6 \%$ \\
\hline 5. & $\begin{array}{l}\text { Start to inhale forcefully through the mouth from } \\
\text { the very beginning. Do not gradually build up the } \\
\text { speed of inhalation }\end{array}$ & 58 & 40 & $79.5 \%$ & $54.8 \%$ \\
\hline 6. & Continue inhaling until the lungs are full & 50 & 35 & $68.5 \%$ & $47.9 \%$ \\
\hline 7. & $\begin{array}{l}\text { At the end of the inhalation take the inhaler out of } \\
\text { the mouth and close the lips. Continue to hold the } \\
\text { breath for as long as possible, or up to } 10 \mathrm{~s}\end{array}$ & 60 & 52 & $82.2 \%$ & $71.2 \%$ \\
\hline 8. & Breathe normally & 3 & 1 & $4.1 \%$ & $1.4 \%$ \\
\hline 9. & If another dose is required, repeat steps $1-8$ & 64 & 53 & $87.7 \%$ & $72.6 \%$ \\
\hline
\end{tabular}

Table 6: Most commonly committed error in the inhalation technique at baseline.

\begin{tabular}{|llll|}
\hline $\begin{array}{l}\text { Type of } \\
\text { inhaler }\end{array}$ & $\begin{array}{l}\text { Commonly } \\
\text { committed } \\
\text { error in step } \\
\text { no. }\end{array}$ & $\begin{array}{l}\text { No. of } \\
\text { patients }\end{array}$ & $\begin{array}{l}\text { Total no. } \\
\text { of patients }\end{array}$ \\
\hline pMDI & 8 & 10 & 10 \\
\hline pMDI+Spacer & 10 & 17 & 17 \\
\hline DPIs & 4 & 64 & 73 \\
\hline
\end{tabular}

Table 7: Most commonly committed error in the inhalation technique after intervention.

\begin{tabular}{|lll|l|}
\hline $\begin{array}{l}\text { Type of } \\
\text { inhaler }\end{array}$ & $\begin{array}{l}\text { Commonly } \\
\text { committed } \\
\text { error in step } \\
\text { no. }\end{array}$ & $\begin{array}{l}\text { No. of } \\
\text { patients }\end{array}$ & $\begin{array}{l}\text { Total } \\
\text { no. of } \\
\text { patients }\end{array}$ \\
\hline pMDI & 8 & 9 & 10 \\
\hline pMDI+Spacer & 10 & 15 & 17 \\
\hline DPIs & 4 & 53 & 73 \\
\hline
\end{tabular}

\section{DISCUSSION}

Treatment guidelines for asthma and COPD focus primarily on pharmaceutically based strategies, but little attention is given to the manner inhalers are handled by the patients. The fact that the best drugs remain ineffective if not deposited to the lung due to poor inhalational technique is a matter of great concern. ${ }^{20}$ Fink and Rubin estimated the annual direct loss due to handling errors was huge, under the premise that $28 \%$ $68 \%$ of patients use their inhalers incorrectly. ${ }^{21}$

This study was aimed at determining the effect of training on handling of inhalers and thereby extrapolating the positive effect to the clinical outcome of the patients measured by pulmonary function test.

In our study, we found that training in the form of practical demonstration of the inhaler technique improved the mean value of scores achieved, which increased from $5.79 \pm 2.58$ at baseline to $8.23 \pm 2.41$ at the end of the study. This finding is in coherence with previous studies where 
it was seen that those who received inhalation instructions in the past were more likely to inhale correctly. ${ }^{22-25}$

The percentage of patients performing all steps of inhalation correctly with pMDI, pMDI+Spacer and DPI rose to $10 \%, 11.7 \%$ and $27.4 \%$, respectively. This finding is in coherence with a systematic review of inhaler devices by Brocklebank et al which combined results from studies of more than one inhaler type, and found that maximum or "ideal" inhaler scores were attained by $59 \%$ of subjects with DPIs, $43 \%$ with MDI alone, and $55 \%$ with MDI plus holding chamber. ${ }^{26}$

Most commonly performed error in the inhalation technique was in step number eight, ten and four by $100 \%$ of patients using pMDI and pMDI with spacer and $88 \%$ of the patients using DPI at baseline which decreased to $90 \%, 88 \%$ and $73 \%$ respectively at the same step after intervention.

McFadden also specified that the most frequent MDI error was failure to coordinate actuation with inhalation, also known as "hand-breathing coordination," followed closely by too short a breath-hold. Other errors included high inspiratory flow, not shaking the MDI prior to use, and stopping to inspire when the MDI spray hits the throat. $^{27}$

In our study, we found that the pulmonary function variables improved but not to a significant extent over a three months period. This highlights the fact that in chronic conditions as asthma and COPD, drastic improvement in lung function cannot be attained in a span of three months and that patients need to be followed up for a longer duration to see significant changes in their lung function. There is definitely a trend towards improvement in pulmonary function variables which can be concluded from better performance at handling inhalers thereby maximising the effect of topically administered drugs. There are studies that have shown that clinical outcomes have improved in patients with asthma and COPD after systematic training of correct methods of inhalation. ${ }^{28,29}$

The predictor for poor use was the type of inhaler in our study ( $\mathrm{p}<0.0001)$ as among the patients using pMDI, only $10 \%$ of the patients could perform all the steps of inhalational technique correctly after intervention, $11.7 \%$ of those using pMDI+Spacer device performed all the steps correctly after intervention while $27.4 \%$ of DPI users performed all the steps of the inhaler technique correctly after intervention. Our study was supported by some other studies where the type of inhaler was a determinant of poor use. ${ }^{30,31}$

Repetition of training at regular intervals enhances the technique of correct inhalation. This fact is also supported by studies as a study by Kamps et al which demonstrated that in newly referred children with asthma correct inhalation technique with MDI and spacer improved from
78.6 to $100 \%$ after three instruction sessions. ${ }^{32}$ As treatment of pulmonary diseases and inhaler therapy go hand in hand, we can capitalize on the treatment being provided by merely improving the method of inhalation through proper training using a standard check-list and repetition of the correct way at regular intervals. Also, proper selection of the device as per the patient's preference can help in reducing errors in techniques of inhalation, thus maximizing benefits of the prescribed medication.

The limitations of this study were lesser frequency of follow ups and short duration of the study where the proper method could not be repeated time and again as we know that the knowledge and practice of using the inhaler wears away with time.

\section{CONCLUSION}

Inhaler techniques improved with systematic training and there was a trend towards improvement in lung function, hence the clinical condition.

Funding: No funding sources

Conflict of interest: None declared

Ethical approval: The study was approved by the Institutional Ethics Committee, No. MC Pharma (PF) PG. (Direct)/-302/14, dated-09-07-2014.

\section{REFERENCES}

1. Newman SP. Inhaler treatment options in COPD. Eur Respir Rev. 2005;14:102-8.

2. Fabbri LM, Hurd SS. Global Strategy for the diagnosis, management and prevention of COPD: 2003 update. Eur Respir J. 2003;22:1-2.

3. Celli BR, MacNee W. Standards for the diagnosis and treatment of patients with COPD: a summary of the ATS/ERS position paper. Eur Respir J. 2004;23:932-46.

4. Global strategy for asthma management and prevention. NHLBI/WHO workshop report number 95-3659. Bethesda, National Institute of Health, 2002. Available at http://www.ginasthma.org.

5. Dolovich MB, Ahrens RC, Hess DR, Anderson P, Dhand R, Rau JL, et al. Device selection and outcomes of aerosol therapy: evidence-based guidelines: American College of Chest Physicians/American College of Asthma, Allergy, and Immunology. Chest. 2005;127:335-71.

6. Newman SP, Pavia D, Clarke SW. How should a pressurized beta-adrenergic bronchodilator be inhaled? Eur J Respir Dis. 1981;62:3-21.

7. Hindle M, Newton DA, Chrystyn H. Investigations of an optimal inhaler technique with the use of urinary salbutamol excretion as a measure of relative bioavailability to the lung. Thorax. 1993; 48:607-10.

8. Crompton GK. Problems patients have using pressurized aerosol inhalers. Eur J Respir Dis Suppl. 1982;119:101-04. 
9. Newman SP. Spacer devices for metered dose inhalers. Clin Pharmacokinet. 2004;43:349-60.

10. Smith IJ, Parry-Billings M. The inhalers of the future? A review of dry powder devices on the market today. Pulm PharmacoTher. 2003;16(2):7995.

11. Serra-Batlles J, Plaza V, Badiola C, Morejon E. Patient perception and acceptability of multidose dry powder inhalers: a randomized crossover comparison of diskus/accuhaler with turbuhaler. J Aerosol Med. 2002;15(1):59-64.

12. Epstein S, Maidenberg A, Hallett D, Khan K, Chapman KR. Patient handling of a dry-powder inhaler in clinical practice. Chest. 2001;120(5):148084.

13. Fink JB, Rubin BK. Problems with inhaler use: a call for improved clinician and patient education. Respir Care. 2005;50:1360-75.

14. Lindgren S, Bake B, Larsson S. Clinical consequences of inadequate inhalation technique in asthma therapy. Eur J Respir Dis. 1987;70:93-8.

15. Wright J, Brocklebank D, Ram F. Inhaler devices for the treatment of asthma and chronic obstructive airways disease (COPD). Qual Saf Health Care. 2002;11(4):376-82.

16. Laube BL, Janssens HM, De Jongh FH, Devadason SG, Dhand R, Diot P, et al. European respiratory society; International society for aerosols in medicine: what the pulmonary specialist should know about the new inhalation therapies. Eur Respir J. 2011;37:1308-31.

17. De Blaquiere P, Christensen DB, Carter WB, Martin TR. Use and misuse of metered-dose inhalers by patients with chronic lung disease. A controlled, randomized trial of two instruction methods. Am Rev Respir Dis. 1989;140:10-6.

18. Shrestha M, Parupia H, Andrews B, Kim SW, Martin MS, Park DI, et al. Metered-dose inhaler technique of patients in an urban ED: prevalence of incorrect technique and attempt at education. Am J Emerg Med. 1996;14:380-4.

19. Fink JB. Inhalers in asthma management: is demonstration the key to compliance? (editorial) Respir Care. 2005;50(5):598-600.

20. Turner MO, Patel A, Ginsburg S. Bronchodilator delivery in acute airflow obstruction. Arch Intern Med. 1997;157:1736-44.
21. Fink JB, Rubin BK. Problems with inhaler use: a call for improved clinician and patient education. Respir Care. 2005;50:1360-75.

22. Broeders ME, Sanchis J, Levy ML, Crompton GK, Dekhuijzen PN: The ADMIT series-issues in inhalation therapy. Improving technique and clinical effectiveness. Prim Care Respir J. 2009;18:76-82.

23. Melani AS. Inhalatory therapy training: a priority challenge for the physician. Acta Biomed. 2007;78:233-45.

24. Guidry GG, Brown WD, Stogner SW, George RB. Incorrect use of metered dose inhalers by medical personnel. Chest. 1992;101:31-3.

25. Hanania NA, Wittman R, Kesten S, Chapman KR. Medical personnel's knowledge of and ability to use inhaling devices. Metered-dose inhalers, spacing chambers, and breath-actuated dry powder inhalers. Chest. 1994;105:111-6.

26. Brocklebank D, Ram F, Wright J, Barry P, Cates C, Davies L, et al. Comparison of the effectiveness of inhaler devices in asthma and chronic obstructive airways disease: a systematic review of the literature. Health Technol Assess. 2001;5(26):1-149.

27. Newman SP, More'n F, Pavia D, Little F, Clarke SW. Deposition of pressurized suspension aerosols inhaled through extension devices. Am Rev Respir Dis. 1981;124(3):317-20.

28. Siafakas NM, Vermeire P, Pride NB, Paoletti P, Gibson J, Howard P, et al. Optimal assessment and management of chronic obstructive pulmonary disease (COPD). The European Respiratory Society Task Force. Eur Respir J. 1995;8:1398-20.

29. Guidelines for the diagnosis and management of Asthma. NIH publication no. 97-4051. Bethesda, MD: $\quad$ NIH; $1997 . \quad$ Available at https://www.nhlbi.nih.gov/files/docs/guidelines/asthg dln_archive.pdf.

30. Diggory P, Bailey R, Vallon A. Effectiveness of inhaled bronchodilator delivery system for elderly patients. Age Ageing. 1991;20:379-82.

31. Van der Palen J, Klein J, Rovers M. Compliance with inhaled medication and self-treatment guidelines following a self-management programme in adult asthmatics. Eur Respir J. 1997;10:652-7.

32. Vincken W, van Noord JA, Greefhorst AP. Improved health outcomes in patients with COPD during $1 \mathrm{yr}$ 's treatment with tiotropium. Eur Resp J. 2002;19:20916.

Cite this article as: Jha T, Sahai AK, Sarkar M, Kaundal PK, Bhardwaj P, Sharma I. Assessment of inhalation technique and predictors of incorrect performance among patients of chronic obstructive pulmonary disease and asthma. Int $\mathbf{J}$ Basic Clin Pharmacol 2016;5:1598-605. 